\title{
EFFECT OF MINERAL AND ORGANIC FERTILIZERS ON YIELD AND TECHNOLOGICAL TRAITS OF SOME BREAD WHEAT VARIETIES
}

\author{
M.E. Ibrahim ${ }^{(1)}$, A.M.S. Hussein ${ }^{(2)}$, A.A. Ali ${ }^{(1)}$ and Amany H.A. Elkoussy ${ }^{(1)}$ \\ (1) Crop Science Department, Faculty of Agriculture, Menoufia Univ., Egypt. \\ ${ }^{(2)}$ Food Technology Department, National Research Centre, Dokki, Cairo, Egypt
}

Received: Nov. 22,2018

Accepted: Dec. 9, 2018

ABSTRACT: Two field experiments were carried out at the Experimental Farm, faculty of Agriculture, Menoufia University, Shebin El-Kom, Egypt during 2015/2016 and 2016/2017 seasons to investigate the effect of various combinations of mineral and organic fertilization systems (mineral nitrogen, organic nitrogen, phosphate ore and potassium ore) beside without fertilization treatment on yield and its components and technological traits of some bread wheat varieties (Gemmeiza 11, Gemmeiza 12, Misr 1, Giza 171 and Sids 13). The results obtained could be summarized as follows:

Fertilization with any mineral and/or organic fertilizers caused increases in most yield and technological characters studied herein. Application of $50 \%$ mineral $N+50 \%$ organic $\mathrm{N} /$ fed was superior to the other fertilization systems in yield and its components (number of spikes/ $\mathbf{m}^{2}$, number of grains/spike, grain yield /fed and straw and biological yields/fed) and technological properties (protein, crude fiber, wet gluten and dry gluten percentages) followed by $100 \%$ mineral $\mathrm{N} /$ fed compared to other fertilization systems especially unfertilized plants which recorded the lowest values. However, the highest values of 1000-grain weight, spike weight and carbohydrates and ash percentages were recorded by application of 50\% organic $\mathrm{N}+$ phosphate ore + potassium ore/fed.

Data indicated that Giza 171 and Gemmeiza 11 varieties surpassed the other varieties in yield and its components (number of spikes/ $\mathrm{m}^{2}$, number of grains/spike, 1000-grain weight, spike weight, grain yield/fed and straw and biological yields/fed) and technological properties (protein, wet gluten and dry gluten percentages) in favor of Giza 171 variety in most economic characters. However, the highest values of carbohydrates and ash percentages were obtained by Gemmeiza 12 and Sids 13, respectively. On the other hand, Misr 1 variety was the inferior variety in most characters studied.

The interactions between fertilization systems and wheat varieties were found to be significant for most characters studied. It could be concluded that Giza 171 variety fertilized with $50 \%$ mineral $N+50 \%$ organic $N /$ fed being the most effective combined treatment for maximizing most effective characters in yield and grain quality, where recorded the highest values of grain yield (3.869 and 3.906 ton /fed in the first and second seasons, respectively) under the environmental conditions of Menoufia governorate.

Key words: Egyptian bread wheat, Varieties, Fertilization, Yield and Grain quality.

\section{INTRODUCTION}

Wheat is the most important cereal crop cultivated in the world and considered as a human stable food for urban and rural societies as well as source of straw for animal feeding
(Ibrahim et al., 2011). Grains are important sources of proteins, dietary fibers, phytochemicals, vitamins and minerals. Grains contains about $\mathbf{1 0 - 1 5} \%$ protein and concentrated sources of starch (Salleh, 2015). Egypt is suffering 
from insufficient local production of wheat. Local production of wheat flour varied annually and covers about only $40-55 \%$ of consumer requirements. In 2017/18 season, the cultivated area of wheat roughly equaled 3.15 million fed which produced in same marketing year about 8.1 million tons. Wheat imports were equaled about $\mathbf{1 1 . 7}$ million tons annually according to Global Agricultural Information Network (GAIN report 2017).

The wheat new varieties have a good yield potentiality but still yield per fed is much less to face the food security threat. Wheat grain yield per unit area involves the number of spikes, number of grains per spike and single grain weight. Grain yield is significantly affect by genetical and environmental factors. Nutrients availability affects plant growth and cause changes in yield and its components (Noureldin et al., 2013 and El-Seidy et al., 2017). Consequently, improving yield and quality of wheat varieties requires deciding fertilizers requirement.

Fertilization with major nutrients cause increases in leaf area, chlorophyll content and dry matter production during vegetative growth period and contributed greatly in raising grain and straw yields (Al Mamun et al., 2012 and Daur 2013). Intensifying cultivation led to use of large amounts of chemical fertilizers, which have become too expensive and cause ecosystem's pollution. Recently, organic manures has received a serious attention to avoid the dangerous of environmental pollution. Organic fertilization sustain soil fertility through affecting physical, chemical and biological properties of soil. Using a mixture of organic and mineral fertilizers improved soil structure and water related characteristics via increasing total porosity, water holding capacity, available moisture, nutrients content and water use efficiency (Shaaban, 2006). Phosphate and potassium ores are agro and industrial natural products. Phosphate ore exist in Egypt in three main provinces (Western desert, Nile valley and Red sea). Upgrading of phosphate ore reduces the phosphatic fertilizers quantity used for the same $\mathrm{P}_{2} \mathrm{O}_{5}$ units, consequently reduces costs for transportation and fertilizer and/or phosphoric acid production (Abouzeid, 2007 and Kandil et al., 2017). Potassium ore (commonly called potash ore) is mined from underground deposits in many parts of the world. It contains iron that imparts a red tint to the final fertilizer that contains $\mathrm{K}_{2} \mathrm{O}$ about $10.10 \%$.

The objective of this recent study is to determine the differences in yield and technological characters of new bread wheat varieties, i.e. Giza 171, Sids 13, Gemmeiza 12 and Misr 1 in comparison with Gemmeiza 11 cultivated under various fertilization systems at Menoufia governorate.

\section{MATERIALS AND METHODS}

Two field experiments were carried out at the Experimental Farm, Faculty of Agriculture, Menoufia University, Shebin El-Kom, Egypt to study the effect of mineral and organic fertilization systems on yield and technological properties of some bread wheat (Triticum aestivum L.) varieties during 2015/2016 and 2016/2017 seasons. Each experiment included 35 treatments, which were the combination of seven fertilization systems and five wheat varieties. The tested experimental treatments are as follow:

\section{A- Mineral and organic fertilization} systems:

1- without fertilization "control"

2- $100 \%$ mineral $\mathrm{N} / \mathrm{fed} \mathrm{"} 75 \mathrm{~kg} \mathrm{~N}$ "

3- $100 \%$ organic N/fed " 6 ton compost"

4- $50 \%$ mineral $\mathrm{N}+\mathbf{5 0 \%}$ organic $\mathrm{N} / \mathrm{fed}$ " $37.5 \mathrm{~kg} \mathrm{~N}+3$ ton compost"

5- $50 \%$ organic $\mathbf{N}+\mathbf{1 0 0} \%$ phosphate ore /fed "3 ton compost $+74 \mathrm{~kg}$ 
phosphate ore"

6- $50 \%$ organic $\mathrm{N}+100 \%$ potassium ore /fed " 3 ton compost + 238 kg potassium ore"

7- $50 \%$ organic $N+100 \%$ phosphate ore $+100 \%$ potassium ore /fed " 3 ton compost $+74 \mathrm{~kg}$ phosphate ore +238 kg potassium ore"

\section{B- Varieties:}

Five bread wheat varieties were evaluated namely, Gemmeiza 11, Gemmeiza 12, Misr 1, Giza 171 and Sids 13.

The recommended fertilizers rate $(\mathbf{1 0 0 \% )}$ for wheat growth under experiment conditions was $75 \mathrm{Kg} \mathrm{N}, 15.5$ $\mathrm{kg} \mathrm{P}_{2} \mathrm{O}_{5}$ and $24 \mathrm{~K}_{2} \mathrm{O}$ /fed for nitrogenous, phosphatic and potash fertilizers, respectively. Nitrogen was added in the form of ammonium nitrate (33.5 \% N).
However, phosphorus and potassium were added in the form phosphate ore $\left(21.0 \% \mathrm{P}_{2} \mathrm{O}_{5}\right)$ and potassium ore $(10.10 \%$ $\mathrm{K}_{2} \mathrm{O}$ ), respectively. Mineral nitrogen fertilizer was divided into three doses; first dose (20\%) applied before sowing, while remain amount $(80 \%)$ was equally splitted and applied before the first and second irrigations. Organic fertilizers (compost) and nature ores (phosphate ore and potassium ore) were applied as one dose and thoroughly incorporated in the soil before sowing. Compost was obtained from the Egyptian Company for Solid Waste Recycling at El-Obour city, Cairo, Egypt. Phosphate and potassium ores were obtained from Al Ahram Mining Company at Al Maadi, Cairo, Egypt. The properties of tested compost and ore are presented in Table (1).

Table 1. Properties of compost and ores fertilizers used in the investigation.

\begin{tabular}{|c|c|c|c|c|c|}
\hline \multicolumn{2}{|l|}{ Compost } & \multicolumn{2}{|c|}{ Phosphate ore } & \multicolumn{2}{|c|}{ Potassium ore } \\
\hline Bulk density (kg m${ }^{-3}$ ) & 650 & $\mathrm{P}_{2} \mathrm{O}_{5} \quad(\%)$ & 21.00 & $\mathrm{~K}_{2} \mathrm{O} \quad(\%)$ & 10.1 \\
\hline Moisture content (\%) & 28.0 & $\mathrm{SiO}_{2} \quad(\%)$ & 11.69 & $\mathrm{SiO}_{2} \quad(\%)$ & 68.9 \\
\hline Water holding compacting (\%) & 204 & $\mathrm{TiO}_{2} \quad(\%)$ & 0.03 & $\mathrm{TiO}_{2} \quad(\%)$ & 0.03 \\
\hline pH (1:10 suspension) & 7.12 & $\mathrm{AL}_{2} \mathrm{O}_{3}(\%)$ & 0.65 & $\mathrm{AL}_{2} \mathrm{O}_{3}(\%)$ & 16.2 \\
\hline EC (1:10 suspension) & 1.51 & $\mathrm{FeO}_{3} \quad(\%)$ & 1.35 & $\mathrm{FeO}_{3} \quad(\%)$ & 0.36 \\
\hline Organic matter (\%) & 27.6 & MnO (\%) & 0.08 & MnO (\%) & 0.02 \\
\hline Total N (\%) & 1.25 & MgO (\%) & 0.61 & MgO (\%) & 0.05 \\
\hline Total P (\%) & 0.60 & $\mathrm{CaO} \quad(\%)$ & 48.34 & $\mathrm{CaO} \quad(\%)$ & 0.47 \\
\hline Total K (\%) & 0.85 & $\mathrm{Na}_{2} \mathrm{O} \quad(\%)$ & 0.65 & $\mathrm{Na}_{2} \mathrm{O}$ (\%) & 3.13 \\
\hline C / N ratio & $16: 1$ & $\mathrm{SO}_{3} \quad(\%)$ & 1.98 & L.O.I* (\%) & 0.70 \\
\hline Available $\mathrm{N} \quad\left(\mathrm{mg} \mathrm{kg}^{-1}\right)$ & 686 & L.O.I* (\%) & 13.62 & & \\
\hline Available P $\quad\left(\mathrm{mg} \mathrm{kg}^{-1}\right)$ & 201 & & & & \\
\hline Available $\mathrm{K} \quad\left(\mathrm{mg} \mathrm{kg}^{-1}\right)$ & 302 & & & & \\
\hline Extractable (Fe) $\quad\left(\mathrm{mg} \mathrm{kg}^{-1}\right)$ & 583 & & & & \\
\hline Extractable $(\mathrm{Mn}) \quad\left(\mathrm{mg} \mathrm{kg}^{-1}\right)$ & 101 & & & & \\
\hline Extractable $(\mathrm{Zn}) \quad\left(\mathrm{mg} \mathrm{kg}^{-1}\right)$ & 57 & & & & \\
\hline Extractable $(\mathrm{Cu}) \quad\left(\mathrm{mg} \mathrm{kg}^{-1}\right)$ & 92 & & & & \\
\hline Total bacteria (Log No. cfu/ml) & 7.13 & & & & \\
\hline
\end{tabular}


M.E. Ibrahim, et al.,

\begin{tabular}{|l|l|l|l|l|l|}
\hline Total actinobacteria (Log No. cfu/ml) & 5.87 & & & & \\
\hline Total fungi (Log No. cfu/ml) & 4.66 & & & & \\
\hline
\end{tabular}

*L.O.I: Loss on ignition

The treatments were arranged in a split plot design with three replications, where the fertilization systems were randomly distributed in the main plots, while wheat varieties were occupied in the sub plots. The tested varieties grains were obtained annually from Wheat Research Department, Field Crops Research Institute, ARC, Giza, Egypt.

\section{Experimental site description}

Before sowing, experimental soil samples were randomly collected from the top soil $(0-30 \mathrm{~cm})$ for estimating some mechanical and chemical properties of soil according to Jackson (1973) and Page et al. (1982). The data of soil analysis are presented in Table (2).

\section{Crop management practices}

Each sub plot area was $10.5 \mathrm{~m}^{2}(3.5 \mathrm{~m}$ long and $3 \mathrm{~m}$ width) consisted of 20 rows with distance $15 \mathrm{~cm}$ between rows. Sowing was done by hand drilled using a rate of 400 grains $/ \mathrm{m}^{2}$ on $10^{\text {th }}$ and $8^{\text {th }}$ November in the first and second seasons, respectively. Other cultural practices were performed as recommended for the district.

\section{Measurements}

\section{A- Yield and its components:}

At maturity stage, yield and its components, i.e. number of spikes/ $\mathbf{m}^{2}$, number of grains/spike, 1000-grain weight (g.), spike weight (g.), grain yield/fed (ton), straw yield/fed (ton), biological yield/fed (ton) and harvest index (\%). Ten guarded spikes were taken from each experimental plot to estimate spikes characters. However, grain, straw and biological yields of the central $\mathrm{m}^{2}$ in each plot were estimated and converted to ton/fed.

\section{B- Technological properties:}

After harvest, grain samples of first and second seasons were mixed (as an average of the two seasons) to estimate the technological properties. Grains were manually cleaned, tempered to reach $14 \%$ moisture content, then milled using Quadrumat Junior flour mill (Model MLV202, Switzerland). The chemical composition, i.e. moisture, protein, fat, ash and crude fiber percentages were determined in whole meal of grains according to A.O.A.C. (2005). Carbohydrates were calculated by difference method. Wet and dry gluten of wheat flour dough were determined according to the method of A.A.C.C. (2000).

\section{Statistical analysis}

All data were analyzed using analysis of variance according to the methods described by Snedecor and Cochran (1980). The statistical analysis was done using CoStat package program, version 6.3 (Cohort software, USA). The differences among the means of different treatments were tested using Least Significant Differences (LSD) at probability $5 \%$.

Table 2. Physical and chemical properties of the experimental soil.

\begin{tabular}{|c|c|c|c|c|c|c|c|c|c|c|}
\hline \multirow{2}{*}{ Properties } & \multirow{2}{*}{$\begin{array}{c}\text { Texture } \\
\text { class }\end{array}$} & \multirow{2}{*}{$\mathrm{pH}$} & \multirow{2}{*}{$\begin{array}{l}\text { E.C. } \\
\text { ds/m }\end{array}$} & \multirow{2}{*}{$\begin{array}{c}\text { O.M. } \\
\%\end{array}$} & \multicolumn{6}{|c|}{ nutrients (ppm) } \\
\hline & & & & & $\mathbf{N}$ & $\mathbf{P}$ & K & $\mathrm{Fe}$ & $\mathrm{Zn}$ & $M n$ \\
\hline
\end{tabular}


Effect of mineral and organic fertilizers on yield and technological

\begin{tabular}{llllllllllll}
\hline $2015 / 16$ & $\begin{array}{l}\text { Clay } \\
\text { loam }\end{array}$ & 7.51 & 0.59 & 1.73 & 29.5 & 9.28 & 316.2 & 3.26 & 0.90 & 2.16 \\
$2016 / 17$ & $\begin{array}{l}\text { Clay } \\
\text { loam }\end{array}$ & 7.43 & 0.58 & 1.76 & 30.3 & 9.11 & 320.7 & 3.02 & 0.92 & 2.09 \\
\hline
\end{tabular}

\section{RESULTS AND DISCUSSION}

A- Yield and its components

\section{A-I. Effect of fertilization systems}

Data presented in Table (3) shows that number of spikes/ $\mathrm{m}^{2}$ was significantly increased by application of all fertilization systems compared to unfertilized plants. The highest increase was obtained by application of $50 \%$ mineral $N+50 \%$ organic $N / f e d, 100 \%$ mineral $\mathrm{N} /$ fed and $50 \%$ organic $\mathrm{N}+$ phosphate ore + potassium ore/fed without significant differences among them in both seasons more than plants which did not receive any fertilization in both seasons. The positive effect of such fertilizers ( $N$, $P$ and $K$ ) on spikes number might be attributed to their roles in increasing the amount of metabolites synthesized, which promoted the numbers of tillers. Similar trend were obtained by Attia and Abd EI Salam (2016) and Al-Amin et al. (2017).

Significant differences in number of grains/spike were recorded among the tested fertilization systems in the two seasons as shown in Table (3). The highest significant numbers were recorded from plants fertilized with $\mathbf{5 0 \%}$ mineral $\mathrm{N}+50 \%$ organic $\mathrm{N} /$ fed followed by $100 \%$ mineral $\mathrm{N} / \mathrm{fed}$ with significant between them in both seasons. However, the lowest grain numbers were obtained when plants did not receive any fertilizers. The positive effects of mineral and organic fertilizers on number of grains /spike were previously reported by Mandic et al. (2015), Adnan et al. (2016) and Attia and Abd El Salam (2016).

Application of all organic and mineral fertilizers either separately or mixed tended to significantly increase 1000- grain weight and spike weight as compared with unfertilized plants in both seasons. The heaviest 1000 - grain weight and spike yield were recorded by $50 \%$ organic $\mathbf{N}+$ phosphate ore + potassium ore/fed and $\mathbf{5 0 \%}$ mineral $\mathrm{N}+\mathbf{5 0} \%$ organic $\mathrm{N} /$ fed in both seasons. However, the unfertilized plants with any organic and mineral fertilizers produced the lightest grain weight and spike yield in the two seasons. In this context, Mengel and Kirkby (2001) stated that translocation of photoassimilate from the vegetative tissues to grains was much affected by plant nutrition status, which leads to promote cells division and buildup of storage capacity. The increments in 1000grain weight and spike weight by application of different fertilizers were previously reported by Khaled (2007), Noureldin et al. (2013) and Mandic et al. (2015).

Grain yield/fed was significantly and positively responded to application of all fertilization systems compared to unfertilized plants (Table 3). It is worthy to mention that the application of $50 \%$ mineral $\mathrm{N}+\mathbf{5 0} \%$ organic $\mathrm{N} /$ fed followed by $100 \%$ mineral $\mathrm{N} /$ fed caused greater increases in seed yield /fed amounted to 31.34 and $27.71 \%$ more than unfertilized plants, respectively as an average of the two seasons. However, $50 \%$ organic N + phosphate ore + potassium ore/fed and $100 \%$ organic $\mathrm{N} / \mathrm{fed}$ treatments ranked as a second in this respect. Therefore, a sustainable use of these organic and nature resources is of prime importance. The increases in grain yield/fed resulting from application of the tested fertilization systems may be consequent to increases in number of spikes/ $\mathrm{m}^{2}$ and spike yield. 


\begin{tabular}{|c|c|c|c|c|c|c|c|c|c|c|c|c|c|c|c|c|c|c|}
\hline 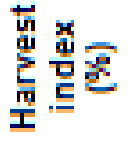 & & 旁 & $\begin{array}{l}\text { 吉 } \\
\text { J }\end{array}$ & ช్ & $\begin{array}{l}\bar{N} \\
\dot{J}\end{array}$ & $\begin{array}{l}\text { क्ठ } \\
\text { フु }\end{array}$ & $\begin{array}{l}\text { 告 } \\
\text { 守 }\end{array}$ & $\begin{array}{l}\text { 今 } \\
\text { ริ่ }\end{array}$ & J & & $\begin{array}{l} \\
\dot{0} \\
\dot{\phi}\end{array}$ & $\begin{array}{l}\mathscr{S} \\
\dot{q} \\
\dot{q}\end{array}$ & 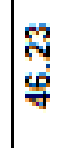 & $\begin{array}{l}\text { gे } \\
\dot{\varphi} \\
\dot{q}\end{array}$ & $\begin{array}{l}\text { 筞 } \\
\text { 它 }\end{array}$ & 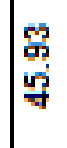 & $\begin{array}{l}\text { 鹦 } \\
\text { 守 }\end{array}$ & 융 \\
\hline 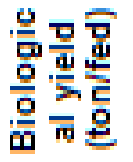 & & $\begin{array}{l}\text { क्ष } \\
\text { फ़ } \\
\text { n }\end{array}$ & 胉 & 売 & 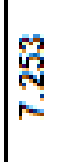 & 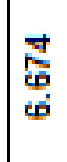 & $\begin{array}{l}\mathscr{\mathscr { B }} \\
\dot{\alpha} \\
\dot{\omega}\end{array}$ & $\frac{2}{\stackrel{5}{5}}$ & 啇 & & $\begin{array}{l}\text { 咊 } \\
\text { n }\end{array}$ & 签 & 总 & 突 & ช్ & 渠 & 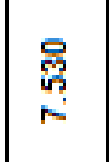 & 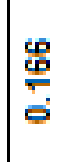 \\
\hline 总总票 & & 啇 & \begin{tabular}{|l}
5 \\
$\mathbf{5}$ \\
$\omega^{2}$
\end{tabular} & 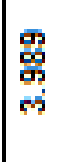 & 을 & 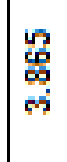 & 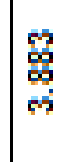 & $\begin{array}{l}\text { 总 } \\
\text { + }\end{array}$ & 哭 & & $\begin{array}{l}\text { 总 } \\
\text { ले }\end{array}$ & 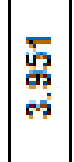 & 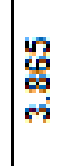 & $\begin{array}{l}\text { 䍚 } \\
\dot{\gamma}\end{array}$ & 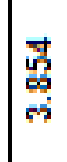 & 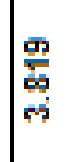 & $\underset{\text { స̃ }}{\text { ปี }}$ & 䓵 \\
\hline 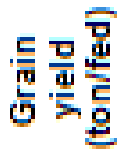 & & ปี & $\frac{9}{g}$ & సू & 筞 & 总 & 㠓 & 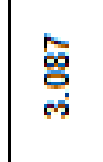 & $\frac{\bar{N}}{0}$ & & $\begin{array}{l}\text { 总 } \\
\text { N } \\
\text { Na }\end{array}$ & 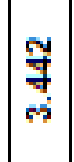 & 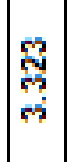 & $\begin{array}{l}\text { 壱 } \\
\text { के }\end{array}$ & 总 & 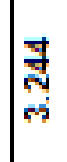 & $\begin{array}{l}\text { 总 } \\
\text { r }\end{array}$ & 둥 \\
\hline 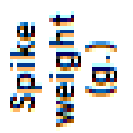 & & 悹 & $\begin{array}{l}n \\
\text { N } \\
\text { N }\end{array}$ & ָ̊ & $\begin{array}{l}\stackrel{p}{N} \\
\text { N }\end{array}$ & 足 & 苟 & $\begin{array}{l}\text { 今్ } \\
\text { N }\end{array}$ & 总 & & ก & 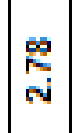 & $\begin{array}{l}\mathbb{N} \\
\mathbb{N}\end{array}$ & 吕 & ก & N & $\begin{array}{l}\text { J } \\
\text { N }\end{array}$ & 总 \\
\hline 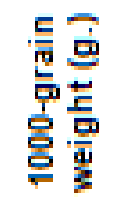 & 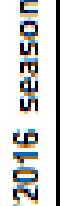 & 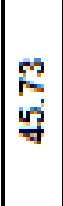 & 管 & 旁 & 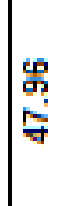 & $\begin{array}{l}\text { J } \\
\text { 今े }\end{array}$ & $\begin{array}{l}\text { 号 } \\
\text { 今 }\end{array}$ & $\begin{array}{l}\text { 号 } \\
\text { go }\end{array}$ & 幽 & 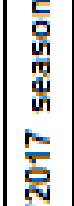 & $\begin{array}{l}\text { 号 } \\
\text { 壬 }\end{array}$ & 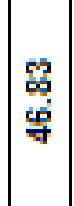 & $\mid \begin{array}{l}8 \\
\dot{6} \\
\dot{q}\end{array}$ & $\begin{array}{l}\text { 号 } \\
\text { 守 }\end{array}$ & $\begin{array}{l}N \\
\dot{q} \\
\dot{q}\end{array}$ & $\begin{array}{l}\stackrel{g}{g} \\
\dot{q} \\
\dot{q}\end{array}$ & 守 & 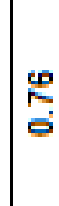 \\
\hline 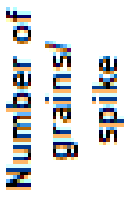 & స్ & कृ & $\begin{array}{l}\overline{7} \\
\text { s. }\end{array}$ & N & 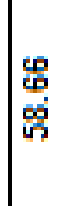 & 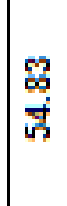 & 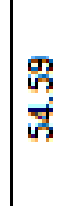 & $\begin{array}{l}\bar{y} \\
\text { ปั่ }\end{array}$ & $\stackrel{N}{\sim}$ & & $\begin{array}{l}\text { w } \\
\text { w } \\
w_{n}\end{array}$ & 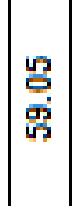 & 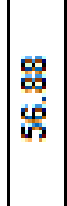 & 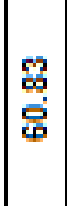 & 疍 & $\begin{array}{l}\text { 志 } \\
\text { 宓 }\end{array}$ & $\begin{array}{l}\text { \% } \\
\text { of } \\
\text { फs }\end{array}$ & $\stackrel{\Sigma}{\leftarrow}$ \\
\hline 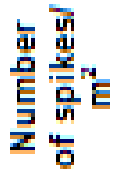 & & 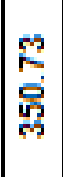 & $\begin{array}{l}\text { के } \\
\text { के } \\
\text { \% }\end{array}$ & 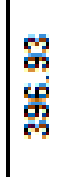 & 号 & 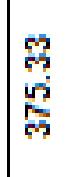 & స̃ & 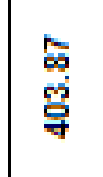 & 告 & & 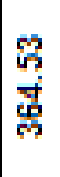 & $\begin{array}{l}\tilde{R} \\
\text { ปิ่ } \\
\text { ปै }\end{array}$ & 䆚 & 㞼 & 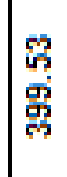 & 令 & 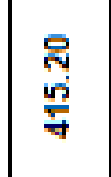 & 氕 \\
\hline 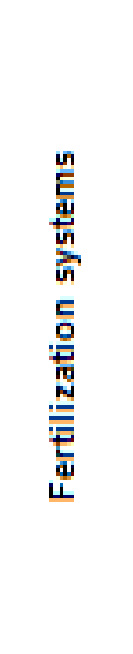 & & 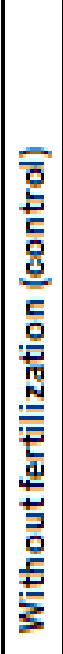 & 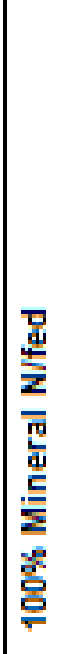 & 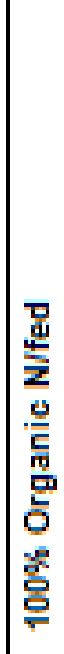 & 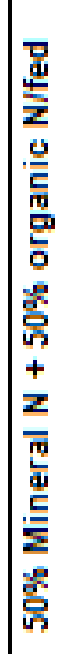 & 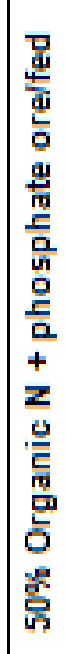 & 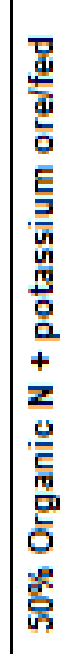 & 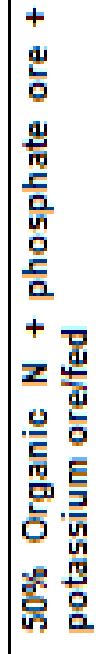 & $\begin{array}{l}\text { 옹 } \\
0 \\
0 \\
0 \\
0 \\
-1 \\
\end{array}$ & & 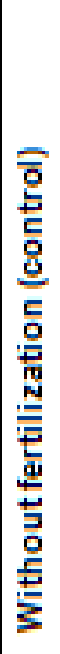 & 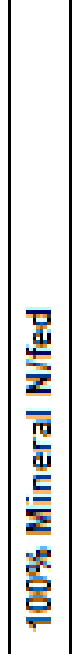 & 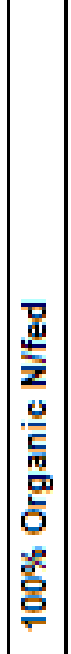 & 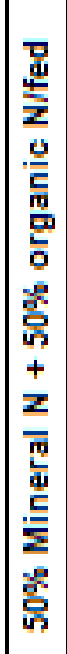 & 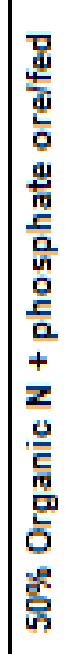 & 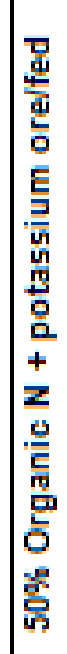 & 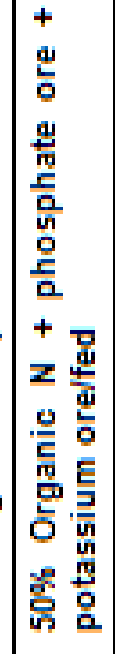 & | \\
\hline
\end{tabular}


may be attributed to the reduction in leaching losses and enhancement nutrients uptake and biological activity (Agamy et al., 2012). In this respect, other researchers found that grain yield of wheat was increased by application of $50 \%$ chemical fertilizer $+50 \%$ poultry manure (Al-Amin et al., 2017), $80 \mathrm{~kg}$ organic $\mathrm{N}+40 \mathrm{~kg}$ mineral $\mathrm{N} / \mathrm{fed}$ (Shaaban, 2006) and $75 \mathrm{~kg}$ mineral nitrogen (Noureldin et al., 2013 and ElSeidy et al., 2017).

With regard to straw and biological yields/fed, data in Table (3) showed that the both traits were significantly affected by all fertilization systems in comparison with unfertilized plants. The plants which received $50 \%$ mineral $\mathrm{N}+50 \%$ organic $\mathrm{N} /$ fed and $50 \%$ organic $\mathrm{N}+$ phosphate ore + potassium ore/fed recorded increases in straw yield amounted to 26.30 and $29.92 \%$ and in biological yield amounted to 28.55 and $27.25 \%$, more than those of unfertilized plants, respectively. This increase in biological yield might be ascribe to the increase in grain yield as well as number of tillers and plant height. These results are in agreement with those obtained by EL-Guibali (2016).

With respect to the variation in harvest index gained from application of fertilization systems, the data in Table (3) indicate that adding $100 \%$ mineral $\mathrm{N} / \mathrm{fed}$ and $50 \%$ mineral $N+50 \%$ organic $N /$ fed resulted significant means higher than those obtained from other fertilization systems. On the other hand, the lowest mean values were produced by adding $50 \%$ organic $\mathrm{N}+$ phosphate ore/fed and $100 \%$ organic $\mathrm{N} / \mathrm{fed}$ in first season and by adding $50 \%$ organic $\mathrm{N}+$ phosphate ore + potassium ore/fed in the second season. These results are in harmony with those obtained by Al-Amin et al. (2017) who mentioned that integrated organic manure $(50 \%)$ with chemical fertilizers $(50 \%)$ was effective treatment for produced the highest harvest index.

\section{A-II. Effect of varietal differences}

Number of spikes $/ \mathrm{m}^{2}$ showed positive response to varietal differences in both seasons as shown in Table (4). Giza 171 followed by Gemmeiza 11 surpassed the other varieties in number of spikes/ $\mathbf{m}^{2}$, while Misr 1 variety gave the lowest number. As an average of the two seasons, Giza 171 and Gemmeiza 11 varieties produced spikes number amounted to 18.26 and $15.42 \%$ more than Misr 1, respectively. Similar results were obtained by Noureldin et al. (2013), Dawood et al. (2014) and El-Seidy et al. (2017).

The results in same table clear that Gemmeiza 11 and Giza 171 varieties having higher number of grains/spike and heavier 1000- grain weight, consequently they were significantly having heavier spike weight. However, Misr 1 variety recorded the last rank. The superiority of such varieties might be attribute to their greater amount of assimilates, which contributed to dry matter accumulation and in turn increase the number of grains/spike and grain weight. In this respect, Abd El-Kreem and Ahmed (2013) and Osman and Nor Eldein (2017) found widely differences among wheat varieties in number of grains/spike, 1000-grain weight and/or spike weight.

Grain yield/fed was remarkably influenced by varieties variation in both seasons. Grain yield /fed ranged between 2.620 to 3.231 ton in the first season and from 2.958 to 3.516 ton in the second season. It is worth noting that Giza 171 variety significantly surpassed other varieties in grain yield/fed followed by Gemmeiza 11 without significant between them in the second season. However, Misr 1 produced the lowest grain yield/fed. It can be notice that Giza 171, Gemmeiza 11, Gemmeiza 12 and Sids 13 varieties excelled Misr 1 variety in grain 
M.E. Ibrahim, et al.,

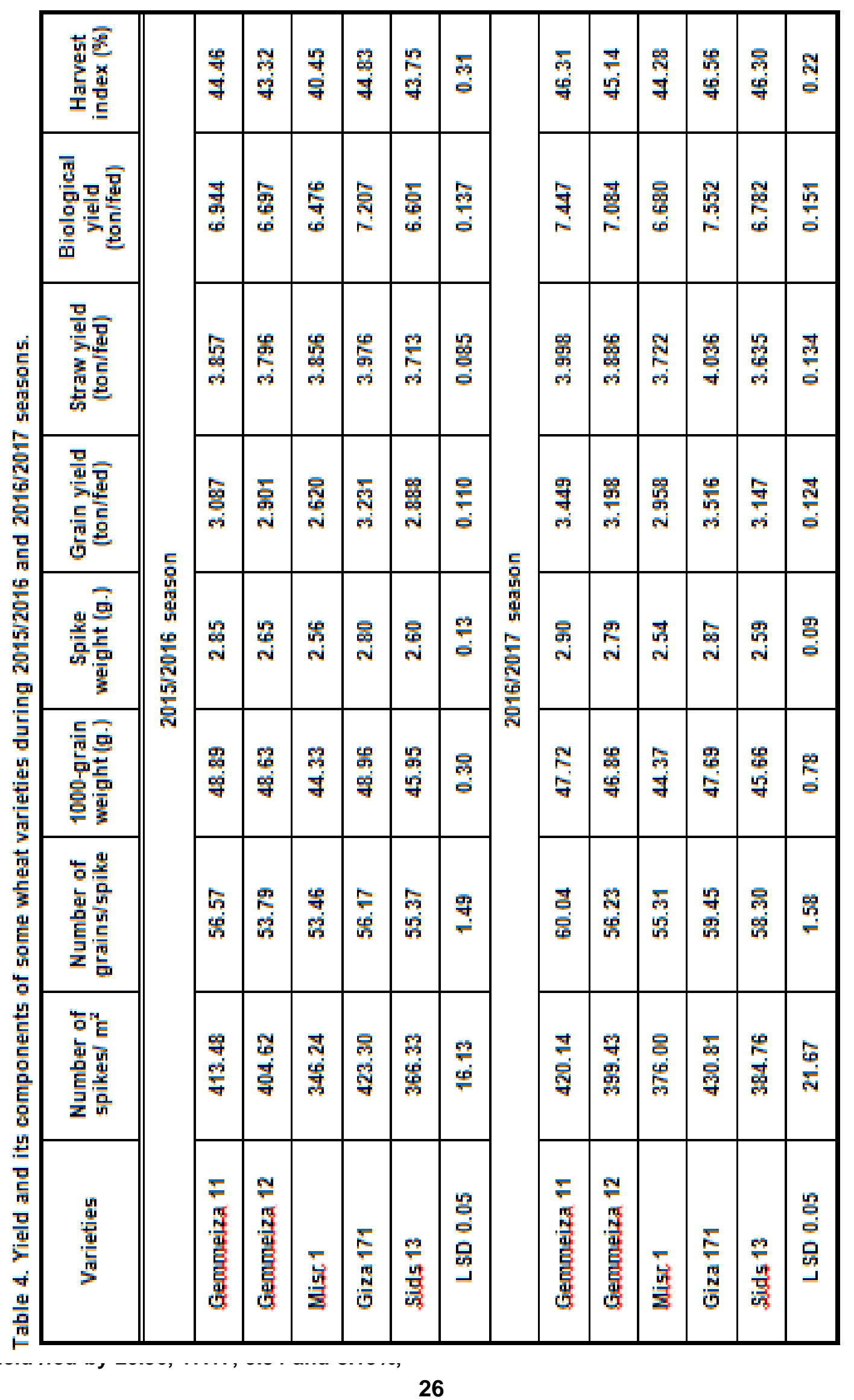


respectively as an average of the two seasons. The superiority of Giza 171 variety might be attributed to its superiority in yield components, i.e. number of spikes $/ \mathrm{m}^{2}$, number of grains/spike and 1000-grain weight. In this respect, other researchers found significant variation among wheat varieties in grain yield in favor of Gemmeiza 10 (Noureldin et al., 2013), Sids 12 (Dawood et al., 2014) and Gemmeiza 11 (Khaled and Hammad, 2014 and El-Seidy et al., 2017).

Significant differences could be detected among the tested varieties with regard to straw and biological yields /fed in both seasons. It is obvious that Giza 171 gave the highest values followed by Gemmeiza 11 in both seasons without significant between them in the second season. Sids 13 produced the lowest straw yield/fed, while Misr 1 variety recorded the lowest biological yield in both seasons. The variation in straw yield might be attributed mainly to the increases in number of tillers and plant height. Varietal differences in straw and biological yields were previously reported by Abdelkhalek et al. (2015) and Osman and Nor Eldein (2017).

Results in Table (4) indicate that Giza 171 variety had significantly higher value of harvest index than the other varieties. Meanwhile, Gemmeiza 11, Sids 13 and Gemmeiza 12 varieties ranked the second in a descending order. On the other hand, Misr 1 variety recorded the lowest mean value in both seasons. This was true in both seasons. It means that Giza 171 has a higher ability of photoassimilate transport to sinks (grains) than the other tested varieties. These results are in harmony with those obtained by El-Seidy et al. (2017).

\section{A-III. Effect of the interaction}

Number of spikes/ $\mathbf{m}^{2}$, number of grains / spike, 1000-grain weight, spike yield, grain yield /fed and straw and biological yields/fed as affected by the significant interaction between fertilization systems and varieties are shown in Figures (1-7). However, harvest index showed insignificant response to this interaction during both seasons, therefore the data were excluded.

It is clear from Figure (1) that Giza 171 variety followed by Gemmeiza 11 had the highest number of spikes $/ \mathrm{m}^{2}$ (469.33 and 465.67) in the first season and (466.67 and 456.00) in second season, respectively when the plants were fertilized with the mixture of mineral and organic fertilizers $(50 \%$ mineral $N+50 \%$ organic $\mathrm{N} / \mathrm{fed}$ ). Moreover, it is obvious that Sids 13 and Misr 1 varieties exhibited the lowest values (312.67 and 321.00) in the first season and (348.00 and 341.33) in second season, respectively when their plants were unfertilized with any mineral and /or organic fertilizers.

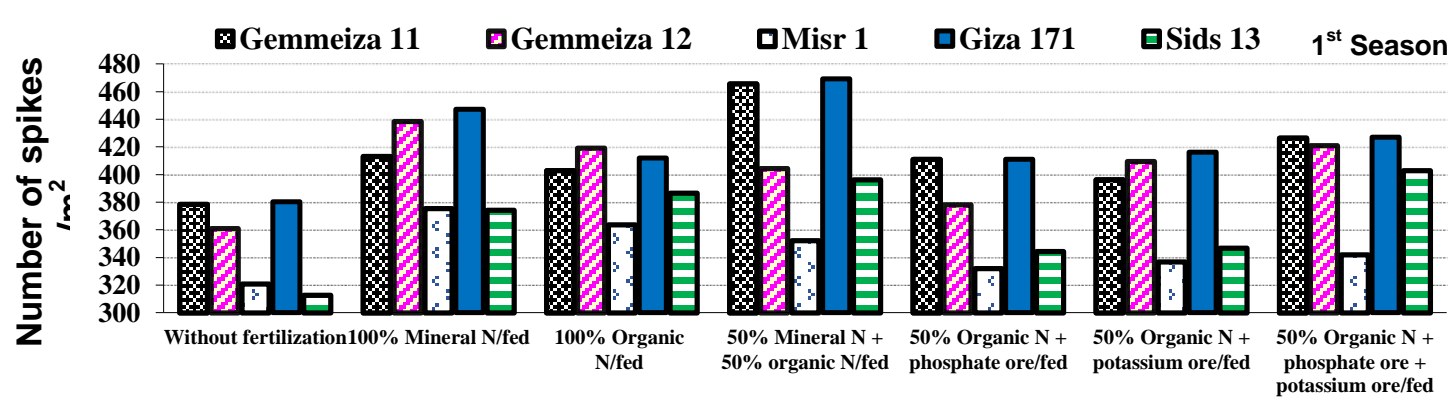




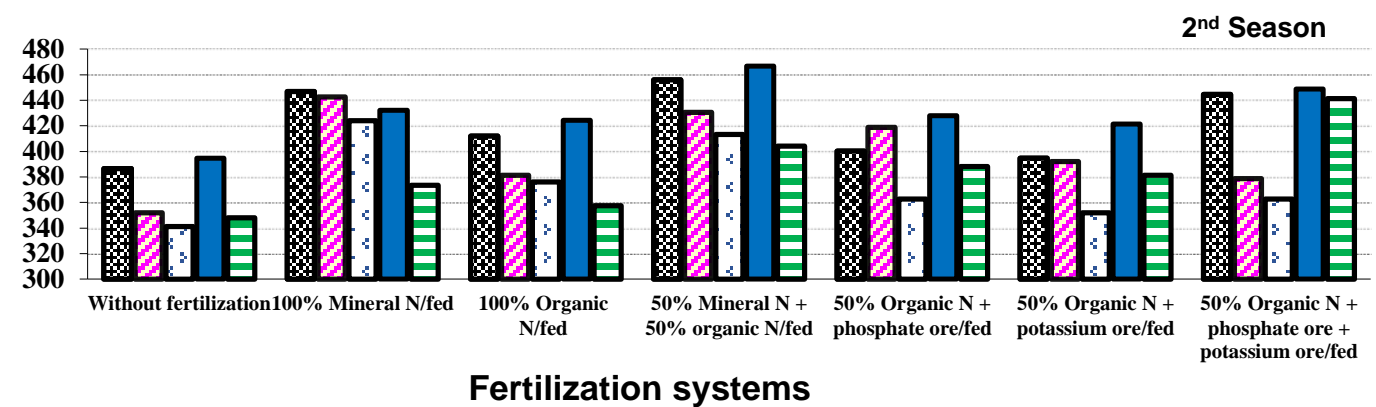

Fig. 1. Effect of interaction between fertilization and varieties on number of spikes $/ \mathrm{m}^{2}$.

With regard to number of grains/spike, significant differences were recorded among the tested fertilization systems and wheat varieties in both seasons (Figure 2). Gemmeiza 11 and Giza 171 varieties were the most superior ones, where recorded the values of 61.63 and 61.33 in the first season and 63.80 and 62.87 in the second season, respectively when fertilized with $50 \%$ mineral $N+50 \%$ organic $\mathrm{N} / \mathrm{fed}$. However, Misr 1 and Gemmeiza 12 varieties were the inferior ones when their plants unfertilized in both seasons. The superiority of Gemmeiza 11 or Giza 171 grown under $50 \%$ mineral $\mathrm{N}+50 \%$ organic $\mathrm{N} / \mathrm{fed}$ in number of grains /spike could be attributed to a greater amount of assimilates which contributed to dry matter accumulation during vegetative period and this in turn increase the number of grains /spike.

It is evident from data illustrated in Figure (3) that there was a considerable amount of variation among the combination treatments in both seasons for 1000-grain weight. Gemmeiza 11 variety had the heaviest grain especially when plants fertilized with $50 \%$ organic $\mathbf{N}$ + phosphate ore + potassium ore/fed and $50 \%$ mineral $\mathrm{N}+50 \%$ organic $\mathrm{N} / \mathrm{fed}$ in both seasons, while Giza 171 exposed its heaviest grain when fertilized with $\mathbf{5 0 \%}$ mineral $\mathrm{N}+50 \%$ organic $\mathrm{N} / \mathrm{fed}$ in both seasons without significant among them. On the other hand, unfertilized plants of Misr 1 was the lighter one in both seasons.

Data in Figure (4) indicated that Gemmeiza 11 variety had the heaviest spike weight when fertilized with $50 \%$ organic $\mathbf{N}+$ phosphate ore + potassium ore/fed and $50 \%$ mineral $\mathrm{N}+\mathbf{5 0} \%$ organic $\mathrm{N} /$ fed in both seasons, while Giza 171 exposed its heaviest spike weight when fertilized with $50 \%$ mineral $\mathrm{N}+50 \%$ organic $\mathrm{N} / \mathrm{fed}$ in both seasons without significant among them. On the other hand, unfertilized plants of Misr 1 variety recorded the lowest values (2.39 and 2.27 g.) in first and second seasons, respectively.

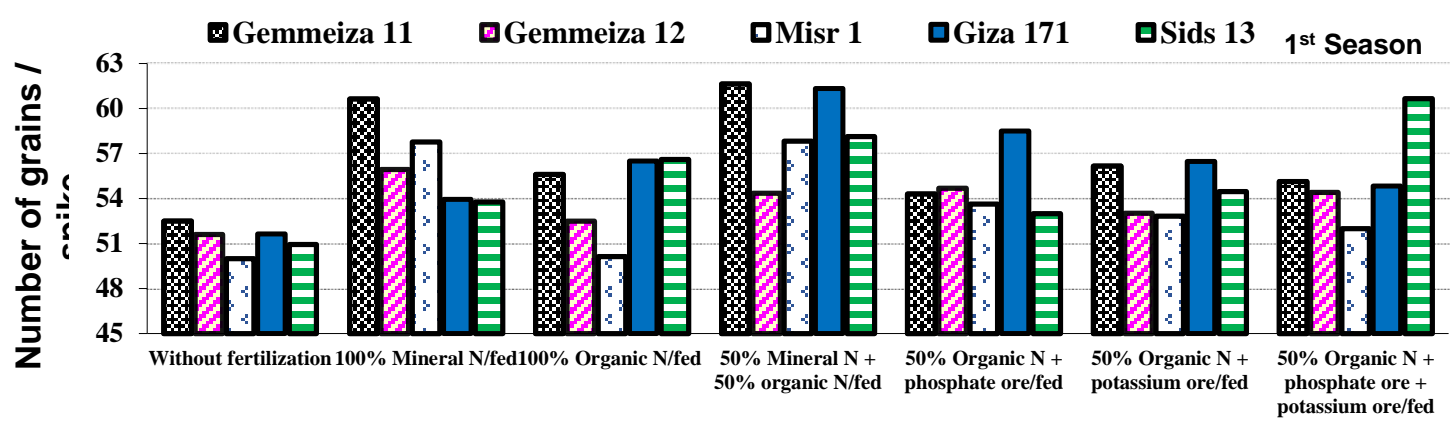




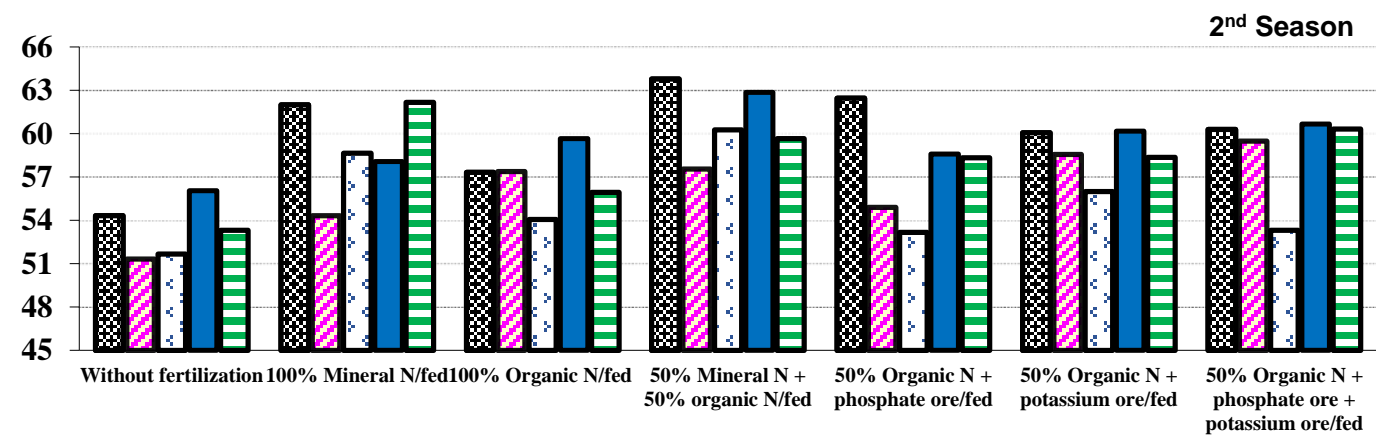

Fertilization systems

Fig. 2. Effect of interaction between fertilization and varieties on number of grains /spike.

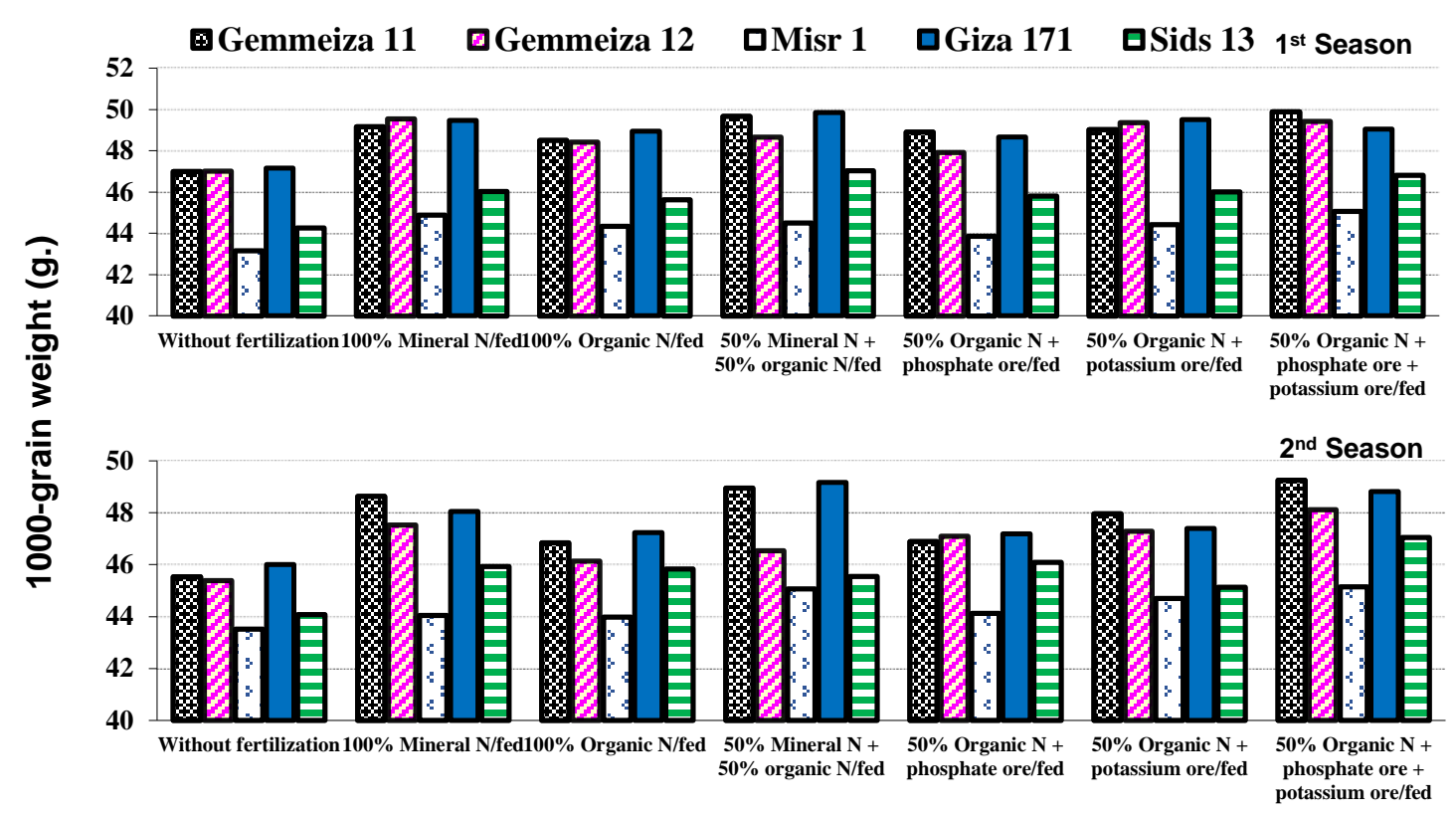

Fertilization systems

Fig. 3. Effect of interaction between fertilization and varieties on 1000-grain weight.

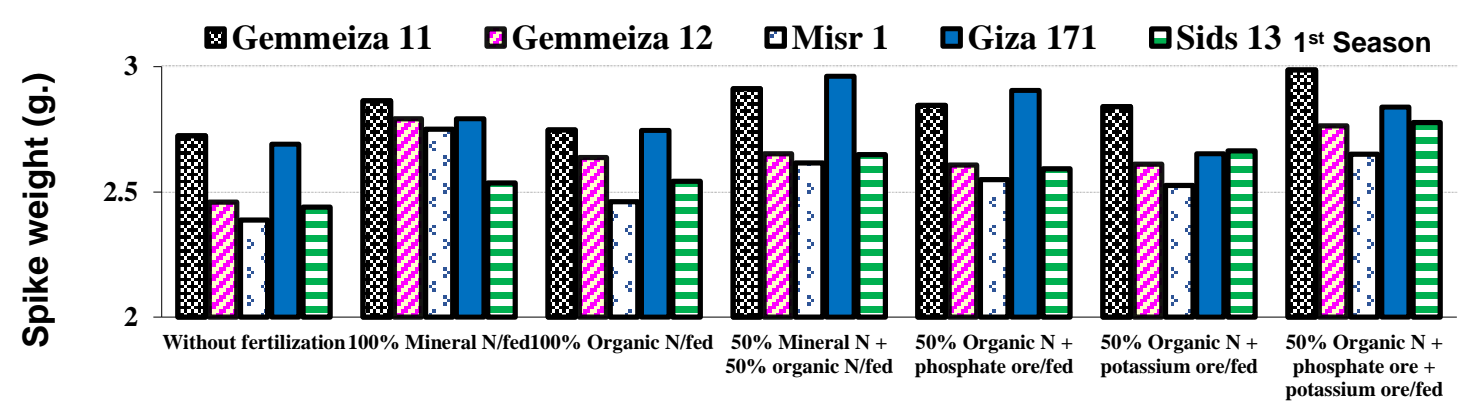




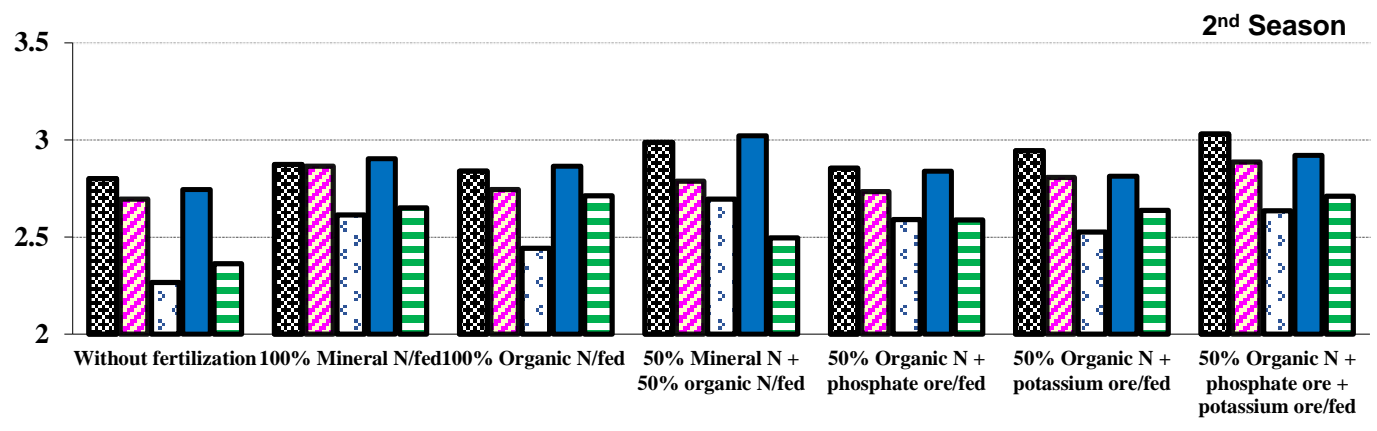

Fertilization systems

Fig. 4. Effect of interaction between fertilization and varieties on spike weight.

It can be noticed from data illustrated in Figure (5) that the tested varieties showed different responses to various fertilization systems from variety to another for grain yield/fed. It is interesting to note that the most pronounced interaction for increasing grain yield /fed was happened when the plants of Giza 171 were fertilized with $50 \%$ mineral $N+50 \%$ organic $N /$ fed where recorded the highest values (3.869 and 3.906 ton) in the first and second seasons, respectively. Moreover, Gemmeiza 11 variety took the second rank when its plants received the same mixture of mineral and organic fertilizers. It can be noticed that fertilized Giza 171 with $50 \%$ mineral $\mathrm{N}+50 \%$ organic $\mathrm{N} / \mathrm{fed}$ caused increases in grain yield/fed which amounted to 36.94, 54.91, 59.91 and 66.06 $\%$ more than the unfertilized Gemmeiza 11, Gemmeiza 12, Sids 13 and Misr 1, respectively as an average of both seasons. However, unfertilized plants had the lowest values in the five tested varieties. These results are in harmony with those obtained by Abdelkhalek et al. (2015), Mandic et al. (2015) and El-Seidy et al. (2017).

It is clear from the data illustrated in Figure (6) that fertilized Gemmeiza 11 plants with $50 \%$ organic $N+$ phosphate ore + potassium ore/fed and Giza 171 with $50 \%$ mineral $\mathrm{N}+\mathbf{5 0} \%$ organic $\mathrm{N} / \mathrm{fed}$ were the more effective treatments in increasing straw yield/fed in the two seasons, where such treatments produced the highest values (4.447 and 4.372 ton/fed, respectively) as an average of the two seasons than the other combination treatments. On the other hand, unfertilized plants had the lowest values in the five tested varieties. Similar results were obtained by Khaled and Hammad (2014).

It is evident from Figure (7) that Giza 171 variety was superior to the other varieties especially when its plants were fertilized with $\mathbf{5 0} \%$ mineral $\mathrm{N}+\mathbf{5 0} \%$ organic $\mathrm{N} / \mathrm{fed}$ where recorded the highest values of biological yield /fed (8.157 and 8.362 ton) in the first and second seasons, respectively. Concerning the different responses of other varieties to various fertilization systems, we noticed that Gemmeiza 11 and Sids 13 exposed their highest biological yields $\mathbf{( 7 . 8 7 0}$ and 7.247 ton/fed, respectively as an average of the two seasons) when fertilized with $50 \%$ organic $\mathrm{N}+$ phosphate ore + potassium ore/fed, while Gemmeiza 12 and Misr 1 varieties produced their highest biological yields (7.416 and 7.243 ton/fed, respectively as an average of the two seasons) when fertilized with $100 \%$ mineral $\mathrm{N} / \mathrm{fed}$. These results are in harmony with those obtained by Abd ElKreem and Ahmed (2013) and Mansour et al. (2016). 


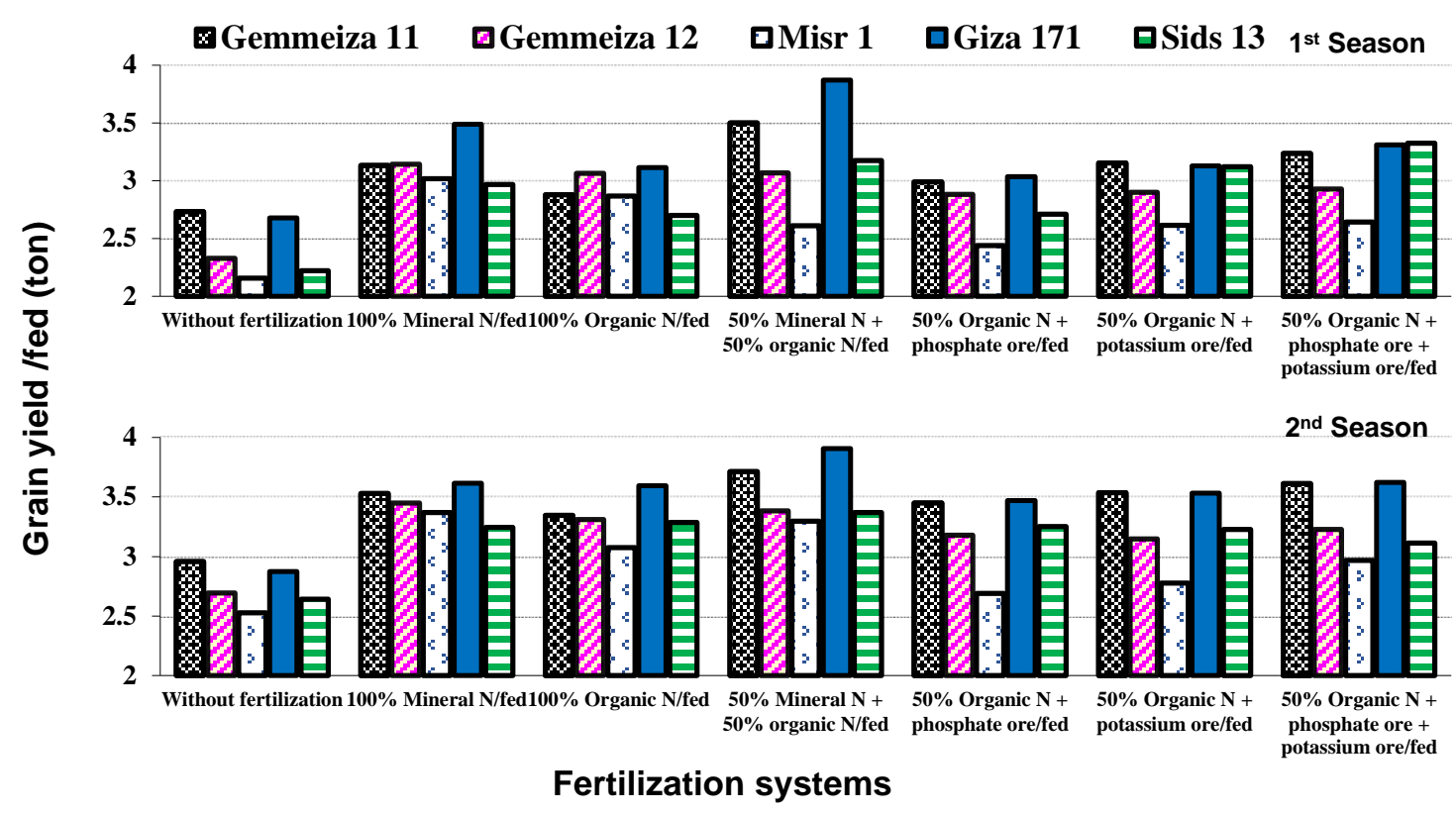

Fig. 5. Effect of interaction between fertilization and varieties on grain yield/fed (ton).

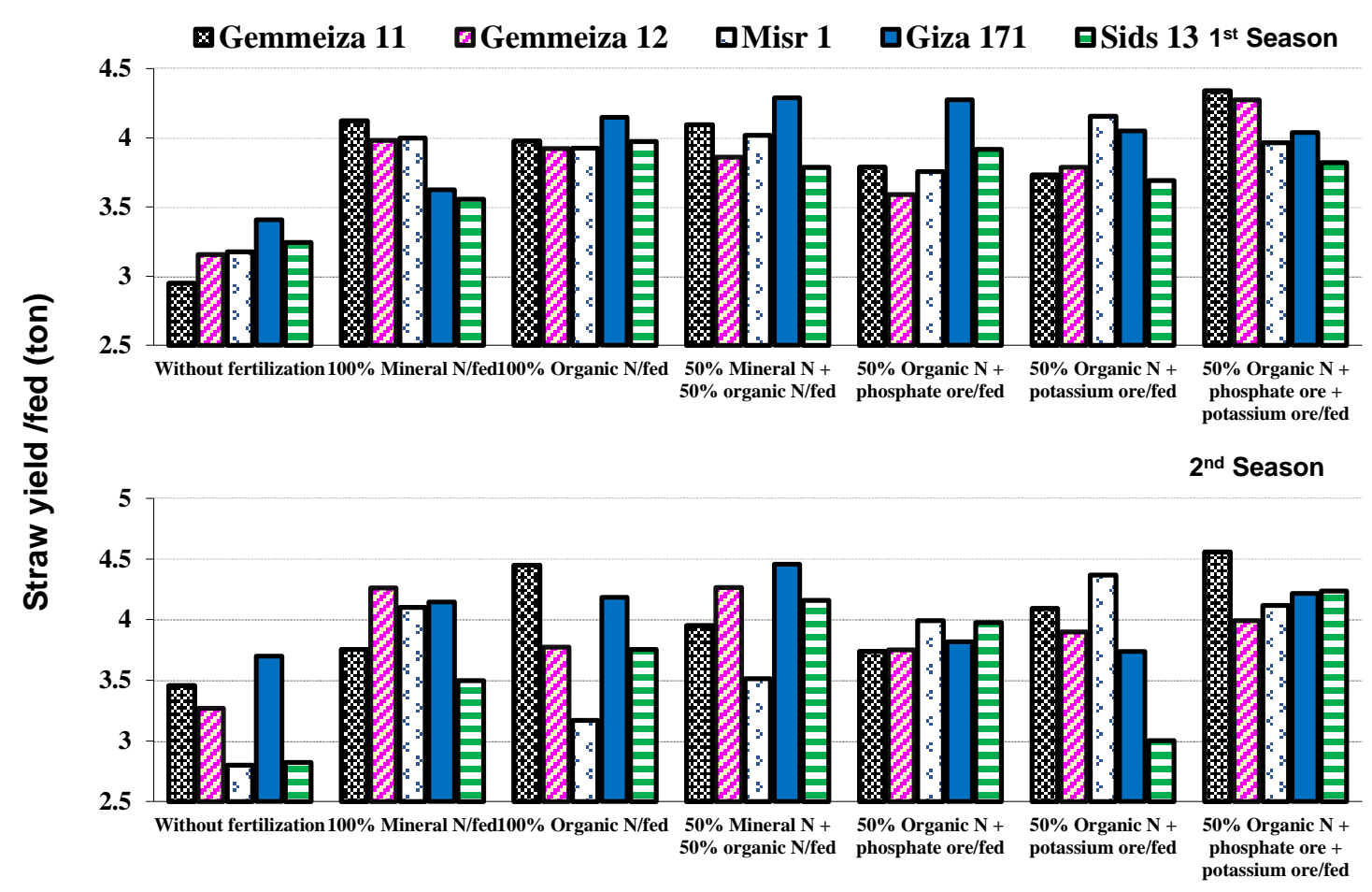

Fertilization systems

Fig. 6. Effect of interaction between fertilization and varieties on straw yield/fed (ton). 


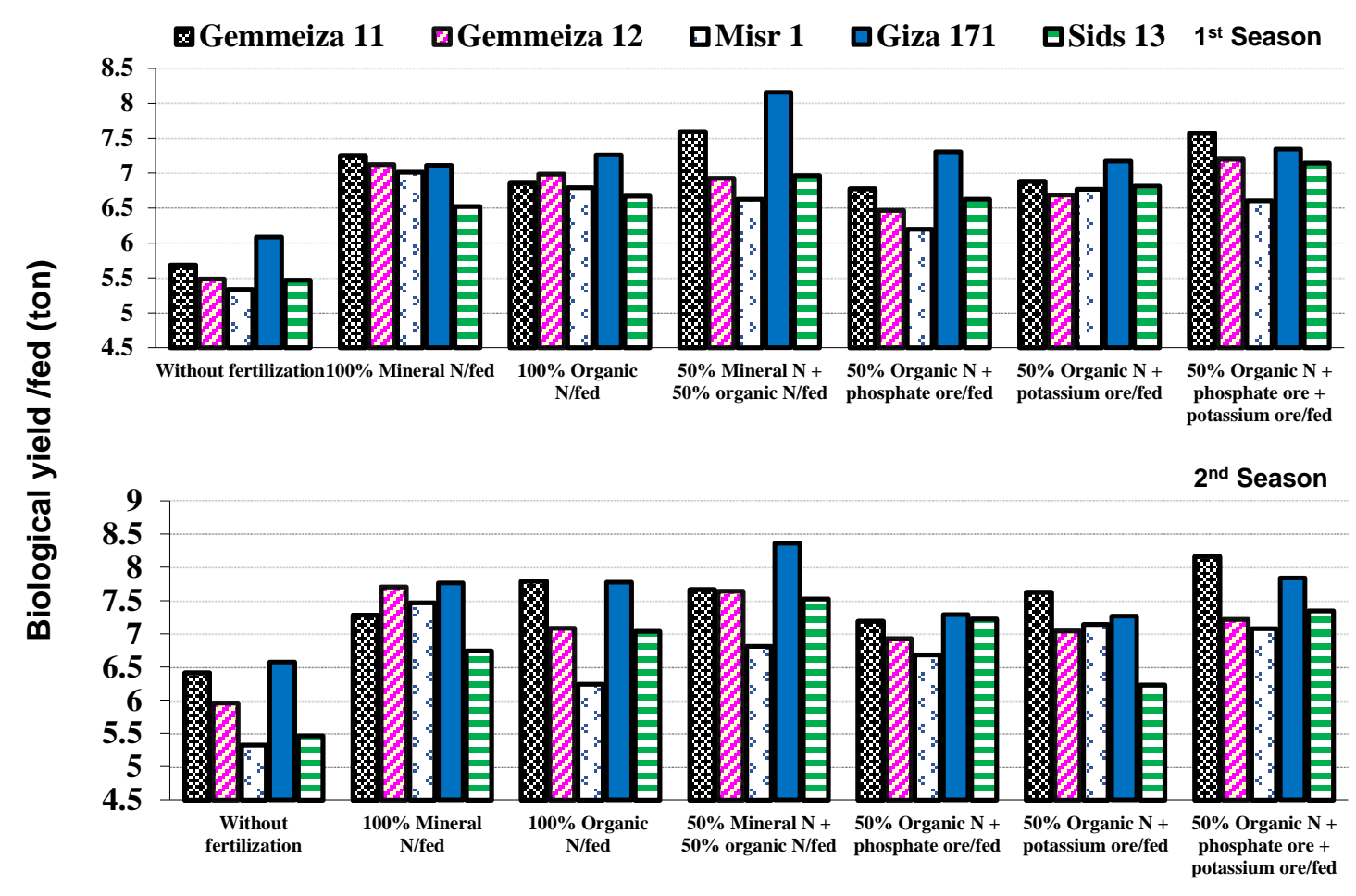

Fertilization systems

Fig. 7. Effect of interaction between fertilization and varieties on biological yield/fed (ton).

\section{B- Technological properties}

B.I. Effect of fertilization systems

Results in Table (5) showed that the effect of fertilization systems on chemical composition of whole meal, i.e. moisture content, protein, carbohydrates, ash, fats and crude fiber. Moisture content of wheat grains were not significantly affected by application of fertilization systems. With regard protein $\%$, it can be noticed that application of $50 \%$ mineral $\mathrm{N}$ + $50 \%$ organic $\mathrm{N} / \mathrm{fed}, \mathbf{1 0 0 \%}$ mineral $\mathrm{N} / \mathrm{fed}$ and $100 \%$ organic $\mathrm{N} / \mathrm{fed}$ seemed to be the most effective treatments for increasing protein percentage, while unfertilized plants took the last rank. Adequate amount of nitrogen in the rhizosphere encourages the absorption of nitrogen in the plant, and this might be a reason of the increase protein \%. The simulative effect of nitrogen on protein percentage might be due its role as a constituent of all amino acids molecules and hence protein synthesis. Moreover, it can be noticed that application of $50 \%$ organic $\mathrm{N}$ + phosphate ore + potassium ore/fed and $50 \%$ organic $N+$ potassium ore/fed produced the highest significant means of carbohydrates \%, indicating the importance of $\mathrm{K}$ element on translocation of sugar and carbohydrates from leaves to the reproductive organs. These results are in accordance with those reported by Khaled (2007) and EL-Guibali (2016).

Fertilized plants with $50 \%$ organic N + phosphate ore + potassium ore/fed and $50 \%$ organic $\mathrm{N}+$ potassium ore/fed exhibited higher ash percentage compared to the other tested fertilizers. On the other hand, unfertilized plants recorded the lowest one. Mean values of fats were insignificantly affected by application of any tested fertilizers compared to unfertilized plants. However, fertilized plants with $50 \%$ mineral $\mathrm{N}+$ $50 \%$ organic $\mathrm{N} / \mathrm{fed}$ and $100 \%$ organic 
$\mathrm{N} /$ fed produced the highest crude fiber content than obtained from rest treatments.

With regard gluten, data in the same table shows that mean values of wet and dry gluten percentages were significantly influenced with application of fertilization systems. In similarity with protein \%, application of $50 \%$ mineral $\mathrm{N}+50 \%$ organic $\mathrm{N} / \mathrm{fed}$ had significant increase in wet and dry gluten $\%$ followed by $100 \%$ mineral $\mathrm{N} / \mathrm{fed}$ and $50 \%$ organic $\mathrm{N}+$ phosphate ore + potassium ore/fed. Meanwhile, unfertilized plants produced the lowest wet and dry gluten \%. In this context, Duska et al. (2001) mentioned that flour quality was determined according to its protein and gluten content. Gluten is rich in gliadins and glutenins. It has been generally associated with total protein content (Ibrahim et al., 2011). Similar results were recorded by Gerba et al. (2013).

\section{B-II. Effect of varietal differences}

Data in Table (6) shows chemical composition of whole meal of wheat varieties. Differences among wheat varieties were not significant for mean values of moisture content. Moisture content of wheat varieties were ranged between 10.87 to $11.45 \%$. Significant increase in protein \% was detected among various varieties. Gemmeiza 11 and Giza 171 surpassed other varieties especially Gemmeiza 12 which ranked the last in this respect. Significant differences were recorded among the tested varieties in carbohydrates. Gemmeiza 12 variety was the superior one and Sids 13 variety was the inferior one. With regard ash percentage, it is obvious that Sids 13 gave the highest value followed by Gemmeiza 12 and Giza 171 varieties, while Gemmeiza 11 produced the lowest value of ash \%. Concerning fats and crude fiber \%, data showed that there are insignificant differences among varieties in both traits. Fats and fiber percentages of all tested wheat varieties were found quite close to each other. These findings are in harmony with those obtained by Hussein et al. (2010) and Dawood et al. (2014).

Table 5 
Table 6. Chemical composition and gluten content of some wheat grain varieties.

\begin{tabular}{|l|c|c|c|c|c|c|c|c|}
\hline \multicolumn{1}{|c|}{ Varieties } & $\begin{array}{c}\text { Moisture } \\
\%\end{array}$ & $\begin{array}{c}\text { Protein } \\
\%\end{array}$ & $\begin{array}{c}\text { Carbohydrates } \\
\%\end{array}$ & $\begin{array}{c}\text { Ash } \\
\%\end{array}$ & $\begin{array}{c}\text { Fats } \\
\%\end{array}$ & $\begin{array}{c}\text { Fiber } \\
\%\end{array}$ & $\begin{array}{c}\text { Wet } \\
\text { gluten } \\
\%\end{array}$ & $\begin{array}{c}\text { Dry } \\
\text { gluten } \\
\%\end{array}$ \\
\hline \hline Gemmeiza 11 & 10.90 & 11.59 & 72.04 & 1.57 & 1.91 & 1.99 & 28.17 & 9.85 \\
\hline Gemmeiza 12 & 11.07 & 10.13 & 73.23 & 1.70 & 1.88 & 1.99 & 24.72 & 8.52 \\
\hline Misr 1 & 11.31 & 10.89 & 72.40 & 1.64 & 1.87 & 1.89 & 26.82 & 9.13 \\
\hline Giza 171 & 10.87 & 11.38 & 72.31 & 1.68 & 1.85 & 1.91 & 28.20 & 9.87 \\
\hline Sids 13 & 11.45 & 11.31 & 71.72 & 1.75 & 1.86 & 1.91 & 27.74 & 9.53 \\
\hline LSD 0.05 & NS & 0.24 & 0.38 & 0.09 & NS & NS & 0.36 & 0.28 \\
\hline
\end{tabular}

Concerning gluten, data in the same table clear that Giza 171 and Gemmeiza 11 were characterized by their higher contents of wet and dry gluten, which reached 28.20 and $9.87 \%$ for Giza 171 and 28.17 and $9.85 \%$ for Gemmeiza 11, respectively. Both varieties were statistically equal in having a higher 
gluten\%. On the contrary, Gemmeiza 12 recorded the lowest content of wet and dry gluten $(24.72$ and $8.52 \%$, respectively). In this concern, Salleh (2015) mentioned that wheat varieties quality depends on many traits, among which the most important include, e.g. protein content, composition of highmolecular glutenin subunits. Similar results were obtained by Ibrahim et al. (2011).

\section{B-III. Effect of the interaction}

The interactions between fertilization systems and wheat varieties were found to be significant, as an average of the both seasons, for protein, carbohydrates, wet gluten and dry gluten percentages (Figure 8). On the contrary, the interactions between the two factors were not significant for moisture content, ash, fats and fiber percentages.

It is evident from Figure (8) that protein \% ranged from 9.68 to $12.23 \%$. Fertilized Gemmeiza 11 or Giza 171 plants with $50 \%$ mineral $\mathrm{N}+\mathbf{5 0} \%$ organic $\mathrm{N} / \mathrm{fed}$ had the maximum values (12.23 and $12.15 \%$, respectively) without significant between them. However, the lowest one $(9.68 \%)$ was obtained especially when Misr 1 plants were unfertilized. Moreover, it can be observed that the increment percentage of protein caused by the best treatments amounted to 26.34 and $25.52 \%$, respectively more than the lowest one.

The interaction effect on carbohydrates \% illustrated in the same figure shows that the highest values were obtained by fertilized Gemmeiza 12 variety with $50 \%$ organic $\mathrm{N}+$ phosphate ore + potassium ore/fed $(74.25 \%), 50 \%$ organic $\mathbf{N}+$ potassium ore/fed $(74.00 \%)$ or $50 \%$ organic $\mathbf{N}+$ phosphate ore/fed (73.78\%). However, the lowest values (71.01 and $71.25 \%$ ) were obtained by Sids 13 when unfertilized and fertilized with $100 \%$ mineral $\mathrm{N} / \mathrm{fed}$, respectively.

Concerning data of wet and dry gluten (Figure 8) indicate that fertilized Giza 171 or Gemmeiza 11 plants with $50 \%$ mineral $\mathrm{N}+50 \%$ organic $\mathrm{N} / \mathrm{fed}$ had the maximum values (30.97 and $30.22 \%$, respectively) for wet gluten and (11.02 and $10.75 \%$, respectively) for dry gluten without significant between them for both traits. However, the lowest significant values were obtained especially when Gemmeiza 12 and Misr 1 plants were unfertilized with any mineral and/or organic fertilizers. These increases in wet 
and dry gluten observed herein by such interaction treatments were logical resultant of the increases in protein percentage as previously reported.
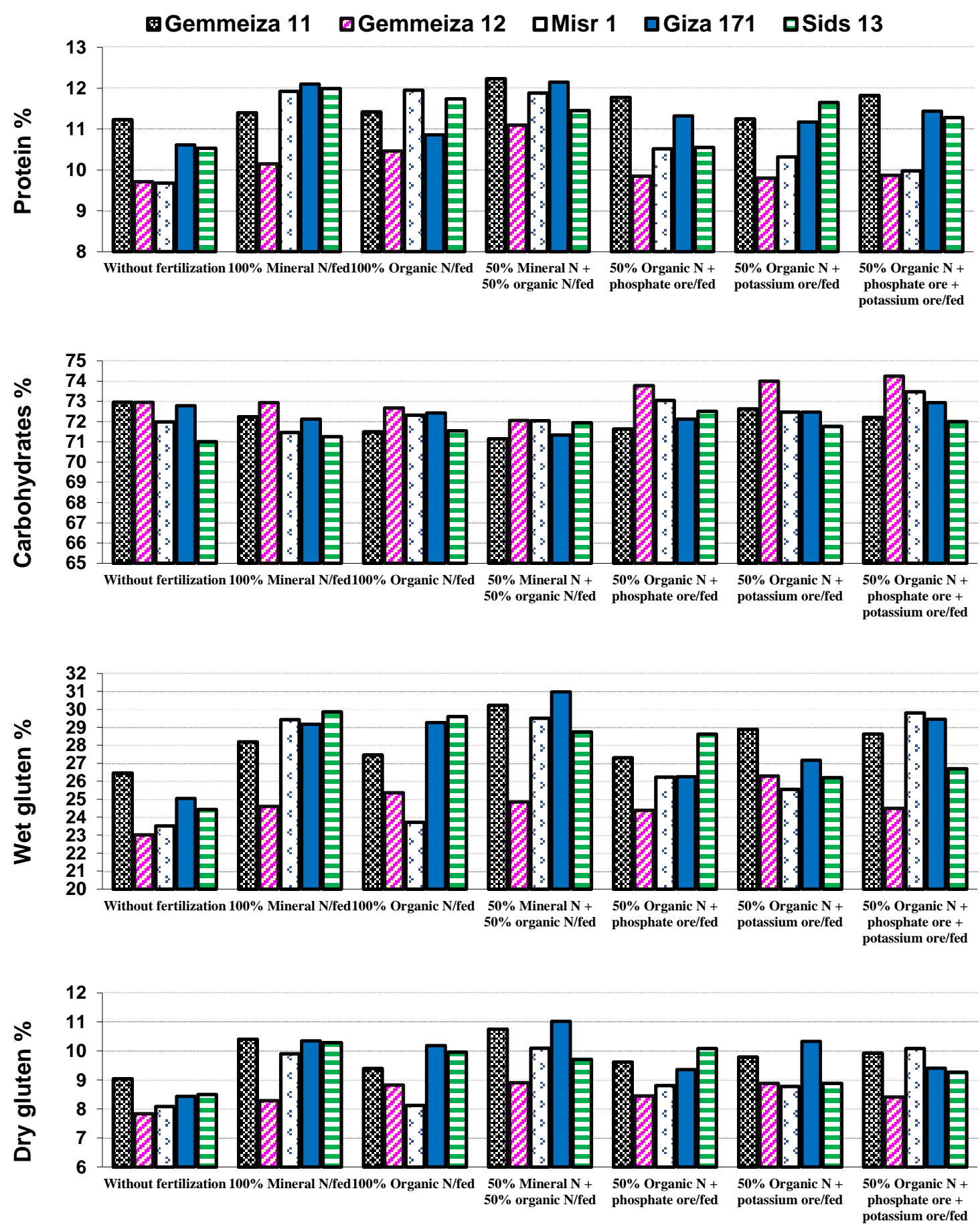

Fertilization systems

Fig. 8. Effect of interaction between fertilization and varieties on technological properties.

\section{Conclusions}

From the abovementioned results, it can be conclude that application of 
organic fertilizers had important effects on yield and quality of wheat. Significant increases in grain yield and most effective characters of quality were obtained by Giza 171 variety when fertilized with $50 \%$ mineral $N+50 \%$ organic $\mathrm{N} / \mathrm{fed}$ which is found to be the best combined treatment for maximize wheat grain productivity (3.869 and 3.906 ton /fed in the first and second seasons, respectively) under environmental conditions of Menoufia governorate.

\section{REFERENCES}

A.A.C.C. (2000). American Association of Cereal Chemists, Approved methods of the American Association of Cereal Chemists $10^{\text {th }}$ ed., St Paul, MN.

Abdelkhalek, A.A., R. Kh. Darwesh and Mona A.M. El-Mansoury (2015). Response of some wheat varieties to irrigation and nitrogen fertilization using ammonia gas in North Nile Delta region. Annals of Agricultural Science, 60 (2): 245-256.

Abd El-Kreem, Thanaa, H. A. and E.G.G. Ahmed (2013). Evaluation of four new bread wheat (Triticum aestivum L.) cultivars in sandy soils under different irrigation regimes and nitrogen fertilizer rates for yield and its components. Alex. J. Agric. Res., 58 (3): 241-250.

Abouzeid, A.M. (2007). Upgrading of phosphate ores - a review. The J. of Ore Dressing, 9 (17): 10-32.

Adnan, M., Z. Shah, Hidayat Ullah, B. Khan, M. Arshad, I.A. Mian, G.A. Khan, M. Alam, Abdul Basir, Inayat-UrRahman, M. Ali and W. Khan (2016). Yield response of wheat to nitrogen and potassium fertilization. Pure Appl. Biol., 5 (4): 868-875.

Agamy, R.A., G.F. Mohamed and M.M. Rady (2012). Influence of the application of fertilizer type on growth, yield, anatomical structure and some chemical components of wheat (Triticum aestivum L.) grown in newly reclaimed soil. Australian J. of Basic and Applied Sciences, 6 (3): 561-570.

Al-Amin, M.A., A.K. Hasan, M.H. Ali, S. Nessa and M.N. Islam (2017). Effect of mulching and organic manure on growth and yield performance of wheat. Archives of Agriculture and Environmental Science 2 (3): 134-140.

Al Mamun, M.D. N., M.D. Safinur Rahman, N.M. Jahangir, M.S. Moula and K.N. Islam (2012). Effect of phosphate rock on the growth and yield of wheat (Triticum aestivum L.) under old Brahmaputra Floodplain soils. The Agriculturists 10 (1): 31-37.

A.O.A.C. (2005). Official Methods of Analysis, $18^{\text {th }}$ ed. Association of Official Analytical Chemists AOAC International, Gaithersburg, MD, USA.

Attia, M.A. and A.A. Abd El Salam (2016). Effect of mineral, organic and biofertilizer on yield and yield components of bread wheat at Siwa Oasis. Alex. J. Agric. Sci., 61 (3): 211219.

Daur (2013). Comparative study of farmyard manure and humic acid in integration with inorganic-N on wheat (Triticum aestivum L.) growth and yield. J. of Agricultural Sciences, 19: 170-177.

Dawood, Mona G., Ebtihal M. Abd Elhamid, Magda A. F. Shalaby and Karima Gamal El- Din (2014). Physiological response of two wheat cultivars grown under newly reclaimed sandy soil to a-tocopherol foliar application. Middle East J. of Applied Sciences, 4 (3): 771-778.

Duska, C., K. Damir, T. Dubravka, P. Biserka and D. Jelena (2001). Gluten as a standard of wheat flour quality. Food Technol. Biotechnol., 39: 353361.

EL-Guibali, Amal H. (2016). Effect of organic and mineral fertilization on wheat yield and quality. J. Soil Sci. and Agric. Eng., Mansoura Univ., 7 (11): 829- 836. 
El-Seidy, E.H., A. A. Morad, R.A. ElRefaey and Nehal Kh. El-Hadidy (2017). Effect of nitrogen fertilizer levels on some wheat varieties belonging two species. Menoufia $J$. Plant Prod., 2 (June): 207 - 217.

GAIN report (2017). USDA'S Global Agricultural Information Network, Grain and Feed Update 2017, December. https://gain.fas.usda.gov/Pages/Defaul t.aspx.

Gerba, L., B. Getachew and W. Walelign (2013). Nitrogen fertilization effects on grain quality of durum wheat (Triticum turgidum L. var. durum) varieties in central Ethiopia. Agricultural Sciences, 4(3): 123-130.

Hussein, A.M.S., M.M. Kamil and G.H. Ragab (2010). Technological Properties of some Egyptian new wheat varieties. J. of American Science, 6 (10): 1160- 1171.

Ibrahim, M.E., S.M. Abdel-Aal, A.S. Hussein and N.A. Gafar (2011). Technological, rheological and yield differences among Egyptian wheat varieties. J. Sci. Food Agric., 91: 831840.

Jackson, M.L. (1973). Soil Chemical Analysis. Prentice Hall of India, Ltd., New Delhi, India, 498 p.

Kandil, A.T., H.I. Mira, M.H. Taha and M.F. Kamel (2017). Production of pure phosphoric acid from El-Sebaeya lowgrade phosphate ore. Separation Science and Technology, 52 (4): 679690.

Khaled, M.A. and S.M. Hammad (2014). Effect of nitrogen and potassium levels on yield and its components of four new bread wheat cultivars. $J$. Plant Production, Mansoura Univ., 5 (1): 95-105.

Khaled, M.A.I. (2007). Productivity of the wheat (Triticum aestivum) cultivar Sakha 94 under water deficit, mineral nitrogen fertilizer and bio fertilizer application. Minufiya J. Agric. Res., 32 (5): 1419-1433.
Mandic, V., V. Krnjaja, Z. Tomic, Z. Bijelic, A. Simic, D.R. Muslic and M. Gogic (2015). Nitrogen fertilizer influence on wheat yield and use efficiency under different environmental conditions. Chilean J. of Agricultural Research, 75 (1) January-March: 92-97.

Mansour, H. A., Sabreen Kh. Pibars, M.S. Gaballah and K.A.S. Mohammed (2016). Effect of different nitrogen fertilizer levels, and wheat cultivars on yield and its components under sprinkler irrigation system management in sandy soil. International J. of Chem Tech. Res., 9 (9):1-9.

Mengel, K. and E.A. Kirkby (2001). Principles of Plant Nutrition. $5^{\text {th }}$ Ed. Dordrecht, Netherlands: Kluwer Academic Publishers, pp: 849. doi:10.1093/aob/mch063.

Noureldin, Nemat A., H.S. Saudy, F. Ashmawy and H.M. Saed (2013). Grain yield response index of bread wheat cultivars as influenced by nitrogen levels. Annals of Agricultural Science, 58 (2): 147-152.

Osman, E.A.M. and Gehan A. Nor Eldein (2017). Response of three bread wheat to nitrogen fertilizer with or without ascorbic acid grown on a clay soil. J. Soil Sci. and Agric. Eng., Mansoura Univ., 8 (6): 267-274.

Page, A.L., R.H. Miller and D.R. Keeney (1982). Methods of Soil Analysis. Chemical and microbiological properties, $2^{\text {nd }}$ Ed. Amer. Soc. Agron. Inc., Publ. Madison, Wisconsin, USA. 
Salleh, Seham Y. G. (2015). Quality evaluation of some cereal products from new wheat varieties. Ph.D. Thesis, Fac. of Agric., Ain Shams Univ., Egypt.

Shaaban, S.M. (2006). Effect of organic and inorganic nitrogen fertilizer on wheat plant under water regime. J. of Applied Sciences Research, 2 (10): 650-656.

Snedecor, G.W. and W.G. Cochran (1980). Statistical Methods, $7^{\text {th }}$ Ed. The lowa State Univ. Press, Ames. Iowa, USA.

تأثير الأسمدة المعدنية والعضوية على الصفات المحصولية والتكنولوجية لبعض

$$
\text { أصناف قمح الخبز }
$$

محمود الاسوقى (براهيم(') ، أحمد محمد سعيد حسين(") ، أحمد عبد الحى على (') ،

أمانى حامد عبد الرشيد القوصى (1)

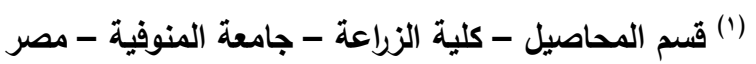

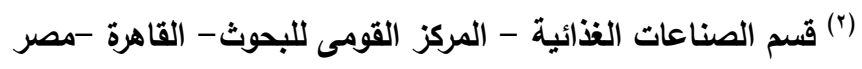

الملخص العربى

أجريت تجريتان حقليتان بالمزرعة البحثية لكلية الزراعة جامعة المنوفية بشبين الكوم بمصر خلال موسي

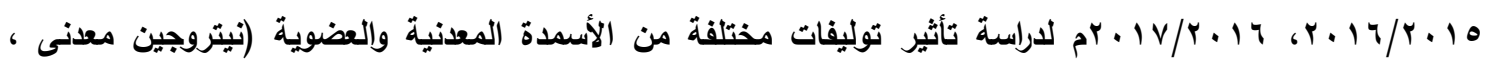

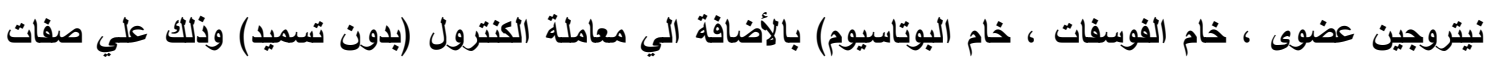

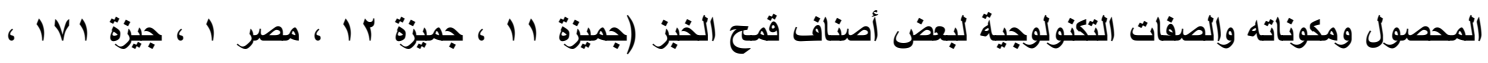

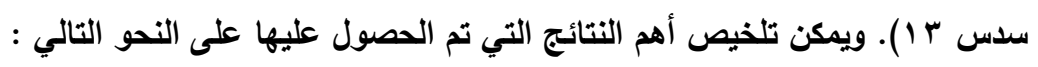

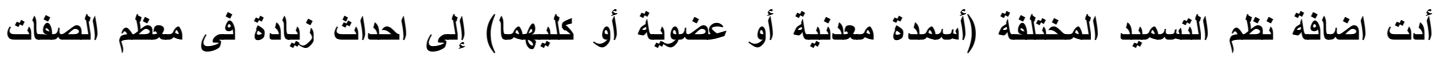

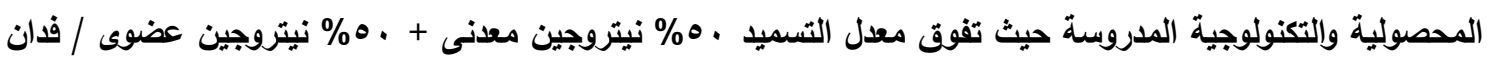

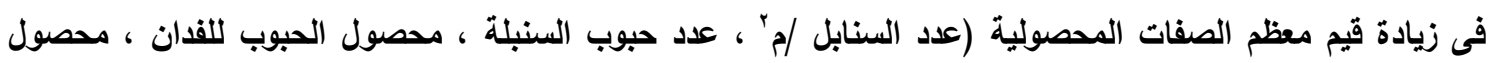

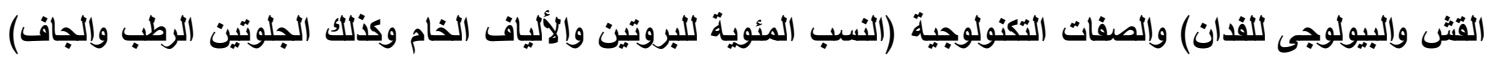

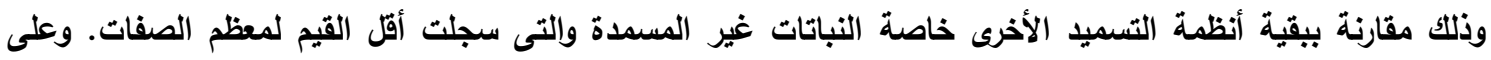

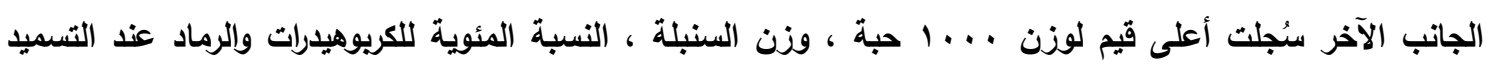
بمعدل • ه\% نيتروجين عضوى + خام الفوسفات + خام البوتاسيوم/ فدان.

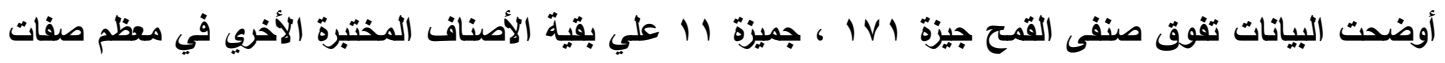

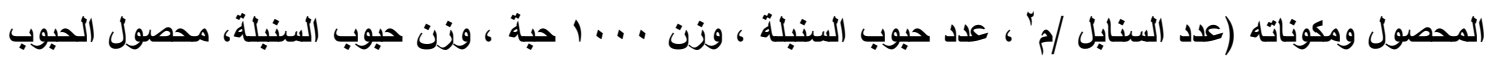

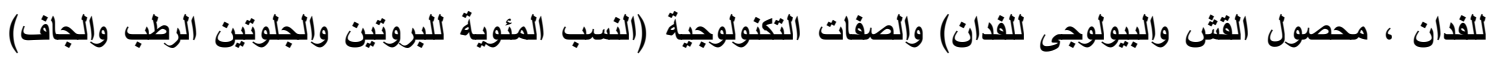

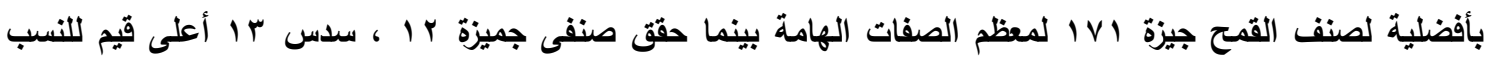

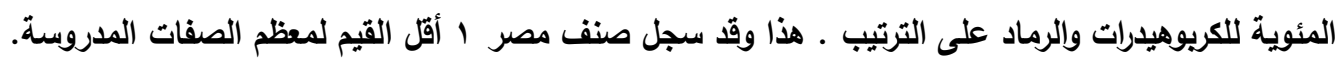

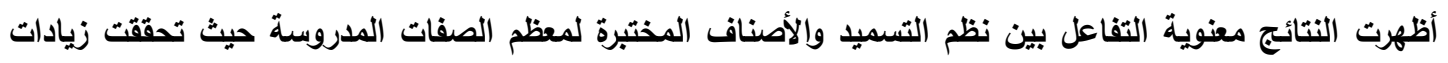

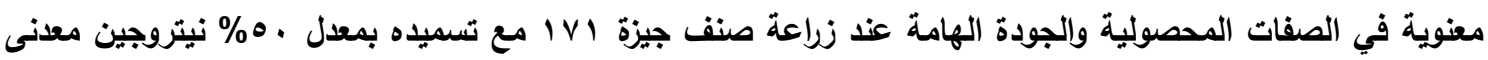


M.E. Ibrahim, et al.,

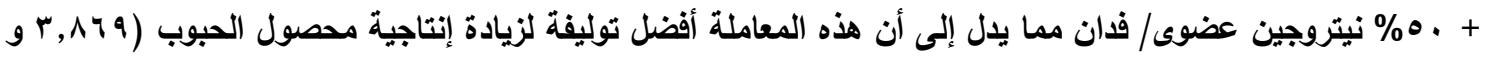

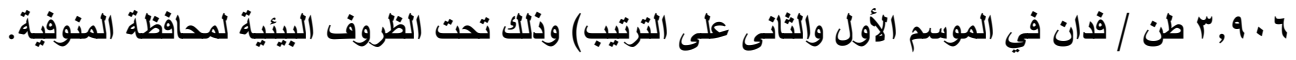

$$
\begin{aligned}
& \text { أ.دماء السادة المحكمين } \\
& \text { أ.د/ شعبان أحمد الشمارقة كلية الزراعة - جامعة المنوفية }
\end{aligned}
$$

